\title{
Deriving Interest Group Ideology \\ from Participation on Amicus Curiae Briefs
}

\author{
Richard A. Almeida
}

Many interest groups are "known" to be ideological actors. Some interest groups self-identify as "liberal," "progressive," or "conservative," while others arguably possess ideologies which can be inferred from their policy platforms, rhetoric, or allies. To date, few attempts have been made to identify and quantify interest group ideology. This paper attempts to demonstrate interest group ideology by recovering one- and two-dimensional ideological mappings from group participation as amici curiae in cases decided by the U.S. Supreme Court from 1999-2003. The results demonstrate that groups' patterns of cooperation and disagreement across cases and years generate a valid and reliable ideological mapping and provides some initial evidence of ideological structuring of lobbying coalitions in amicus briefs.

Like all political actors, interest groups have preferences. Interest groups express their preferences in many of the same ways other actors do: by contributing resources to political organizations and candidates, mobilization efforts, litigation, and through what is likely the activity most closely identified with organized interests, "lobbying," which can be generally conceptualized very broadly as attempting to influence decision-makers.

I use the term "interest group" to denote any organized entity that that makes policy demands on government. This includes, but is not limited to actual membership organizations such as the National Rifle Association or American Civil Liberties Union, businesses, trade associations, labor unions, policy institutes, and advocacy organizations (Baumgartner and Leech 1998, xxii). The strategy developed herein is sufficiently robust so as to accommodate the lobbying activities of all these types of actors, so there is no theoretical reason to exclude any of them.

Similar to Members of Congress, interest groups frequently have the opportunity to express their preferences in a binary fashion - by choosing to lobby for or against a particular phenomenon. Comparably, patterns in these revealed preferences should be able to be analyzed and interpreted (Poole and Rosenthal 1997). This project uses preferences revealed by interest

RICHARD A. ALMEIDA is an assistant professor of Political Science and Geography at Francis Marion University.

An earlier version of this article was presented at the 2004 Annual Meeting of the Midwest Political Science Association. I greatly benefited from the comments and suggestions of Frank Baumgartner, James Endersby, Kevin Esterling, Mel Hinich, Marie Hojnacki, Gary King, Gary McKissick, and several anonymous reviewers. Any errors that remain are mine.

The American Review of Politics, Vol. 32, Fall, 2011: 259-278

(c)2011 The American Review of Politics 
group lobbying of the U.S. Supreme Court as amici curiae to capture patterns of advocacy and unfold a measurement of interest group ideology. The evidence shows that a single ideological dimension explains more than 86 percent of the variation in interest group amicus activity. This mapping correlates well with previous attempts to capture interest group ideology, and has the added benefit of relying only on preferences revealed by interest group activity, not ratings of legislators or other intermediaries.

\section{Interest Group Lobbying of the U.S. Supreme Court}

Organized interests use the courts to pursue their policy goals in a manner similar to how they utilize the other branches of government. That is, groups use the courts when it is strategically advantageous for them to do so, subject to resource and institutional constraints (Hansford 2004; Holyoke 2003; McGuire 1994). There appears to be wide consensus among both students of organized interests and the courts that group use of courts is: a) widespread, b) growing, and c) diverse (see, for example, Baumgartner and Leech 1998; Berry 1997; Caldeira and Wright 1998; 1990; Epstein and Rowland 1991; Holyoke 2004; Koshner 1998; Lowery and Brasher 2004; Nownes 2001; Schlozman and Tierney 1986; Spriggs and Wahlbeck 1997). Current scholarship on organized interests acknowledge a variety of ways in which the courts are accessible to interests, including, but not limited to, acting directly as a party to litigation, institutional sponsorship of litigants, and the filing of amicus curiae briefs (Schlozman and Tierney 1986).

Principles of U.S. jurisprudence and the rules of the U.S. Supreme Court specifically allow parties not directly involved in a lawsuit to file supplementary information as "friends of the court," or amici curiae. Amicus participation takes the form of "providing the court with written briefs ... that presents the group's views on the issue before the court (Schlozman and Tierney 1986)." Both individuals and organized interests can file briefs as amici, and amicus filing has generally increased over the past 50 years (Koshner 1998), but it is well documented that, in particular, amicus participation by organized interests has increased dramatically, making patterns of interest group activity before the court an interesting avenue of research in its own right (Caldeira and Wright 1990) as well as a potentially fruitful source of quantitative data (Baumgartner and Leech 1998, 141).

\section{Interest Groups as Ideological Actors-Previous Work}

Hinich and Munger end the first chapter of their book, Ideology and the Theory of Political Choice, with the statement: "Politics without ideology is Babel" $(1994,21)$. The quote summarizes perfectly the authors' main focus; 
that while policy in and of itself is of vital importance to the scientific study of politics and government, policy decisions and preferences are made in the context of an ongoing battle between consistently opposed sets of ideas, or ideologies. To Hinich and Munger, ideologies provide understandable and consistent answers to perennial questions about both the proper means and ends of government. In this context, an ideology is much more than the net result of some bundle of policy preferences, in fact, ideology in many ways precedes policy positions.

Hinich and Munger define ideology as, "[A]n internally consistent set of propositions that makes both proscriptive and prescriptive demands on human behavior." (Hinich and Munger 1994, 11) Their definition differs from those advanced by many other scholars, but, they claim, their definition and model of political choice have the advantages of, in their words, "verisimilitude." They argue that citizens think ideologically and spatial models account for many observed empirical regularities $(1994,61)$.

Hinich and Munger reject the view that ideology is simply a summary of individual policy positions located in an $n$-dimensional space. Instead, they argue that ideologies frequently precede, and often imply, the policy positions of political parties and candidates. To them, "[c]onsistent actions, justified in consistent ways, are the origins of ideologies" $(1994,15)$. That is, individuals evolve explanations for why they do the things they do, and competing claims for resources turn into discussions of the principles under which disputes over resources ought to be resolved, now and in the future.

However, partaking of ideology is not without cost. A major thrust of their theory is that ideology imposes constraints on behavior. An ideology makes statements about what is good and bad, about what should or should not be done. Ideologies convey information. In the spatial sense, this limits the ability of political actors to locate themselves anywhere in the policy space. Actors perceived as taking actions that violate their ideology run the risk of losing the support of allies/members, who can come to doubt that the actor lives up to its espoused values.

Last, Hinich and Munger focus on political parties as the primary proponents of ideology, and the central actors in the political process. They explicitly disavow ideological orientations of interest groups. Their depiction of interest groups is worth quoting at length:

Pressure groups focus only on a few, or even a single, issue. There need be no overarching set of ethical norms or ideas; pressure groups want what they want because they want it. Party ideologies represent a recounting of the shared ideas of a coalition of interests, but pressure groups focus on an interest or idea that may have no relation to any other policy $(1994,92)$. 
I argue that the above passage represents an incomplete and inaccurate depiction of interest group activity. To be sure, there are single issue and few-issue groups. However, there also exists a large number of organized interests that are organized explicitly around the exact sorts of ideologies elaborated by Hinich and Munger's theory. I argue that many of the reasons why ideology is essential to political parties apply equally well to interest groups, and that many of the choices made by interest groups should be attributable to ideology. While this line of research is underdeveloped in the contemporary literature on interest groups, what existing literature there is on this topic implies strongly that the interactions between interest groups is at least in part structured ideologically.

The empirical literature on interest groups demonstrates, among other things, that interest groups tend to lobby legislators who share the group's policy goals (Hojnacki and Kimball 1998). It is also established that "lobbyists seek out those with similar preferences to share information," (Carpenter et al. 2004, 226). Kollman argues $(1997,523)$ that "interest group activity ... does tend to be targeted toward sympathetic lawmakers."

An early attempt to capture interest group ideology comes from Poole and Romer (1985). In this research, they evaluate PAC contributions from the 1979-80 election cycle, setting forward a straightforward spatial model wherein PACs contribute to candidates based on ideological proximity $(1985,65)$. They explicitly evaluate whether PAC donations are consistent with an ideological mapping of legislators, as opposed to contributions being geared toward maintaining access or building geographical bases of support.

Their results are noteworthy. Using multidimensional scaling techniques on almost 16000 ratings issued by 36 interest groups, Poole and Romer find that a single dimension explains more than 83 percent of the variance of those ratings $(1985,71)$. The authors go on to unfold the ratings results themselves on the groups that issue them, generating a one-dimensional ordering of the 36 groups.

The results of their unfolding are intuitively appealing. Groups that received a negative coefficient can plausibly be termed "liberal." The groups anchoring the left hand side of their mapping include: Americans for Democratic Action, the American Civil Liberties Union, and the National Education Association, to list just three. Three groups on the far right side of the mapping are: Americans for Constitutional Action, the American Conservative Union (ACU), and the Committee for Survival of a Free Congress.

Despite these promising early results, exploration of interest group ideology has not flourished. By way of attempting to demonstrate media bias, Groseclose and Milyo (2005) offer convincing evidence of ideological orientation in what they term "think tanks." They measure how many times various media outlets cite certain policy organizations, and compare that to 
how many Members of Congress cite those same sources. The logic is straightforward: by and large, liberal Members of Congress ought to cite liberal sources of information, and the same for conservative legislators, with certain caveats.

Groseclose and Milyo score each think tank by examining the ideology (using ADA scores) of each legislator who cites each organization, and weighting that by the number of citations. Therefore, if the most conservative (liberal) legislators consistently rely on the same organizations, over and over again, for their information, it follows that those organizations are themselves conservative (liberal). In their Table 1 (2005, 1201), they present the average ADA scores of legislators citing each of 20 think tanks, weighted by both the number of sentences mentioning each group and by the number of citations each group received.

Like the results unfolded by Poole and Romer (1985), Groseclose and Milyo's results are intuitively satisfying. Their measure of group ideology places the Heritage Foundation far on the conservative side, close to the National Right to Life Committee, National Taxpayers' Union, and Cato Institute, to name just a few. The Brookings Institute is depicted as relatively centrist, though "left" of center, and moving increasingly to the liberal side brings in Amnesty International, the AARP, and Common Cause, among others. Interestingly, their results position the ACLU as more conservative than the Brookings Institute and the RAND Corporation as more liberal than either the ACLU or Brookings. Despite these peculiar results, the general ordering of groups shows a high degree of face validity.

McKay (2008) applies a substantially similar technique to 72 interest groups who rate members of Congress. McKay's work essentially "reverse engineers" the interest group ratings of Members. She takes the votes that each group uses to calculate its scores, and then matches those votes to the Members who voted in accordance with the group's preferences, generating a list of who had a "perfect" rating from the group. McKay then takes the DW-NOMINATE (Poole and Rosenthal 1997) score for each "perfect" member, and averages them to extrapolate what is essentially a DWNOMINATE score for each interest group (McKay 2008, 70).

The ideological mapping thus derived shows a high degree of clustering around the middle of the distribution. Indeed, McKay's Figure 1 shows a cluster of 49 groups $(85.9 \%$ of the groups pictured) whose ideologies vary by less than .194. Within the cluster, it is very difficult to discern meaningful differences between groups. It appears that the groups that rate legislators operate within a framework that limits their utility for extrapolating group ideology.

The clumping is likely an artifact of the scoring procedure. Interest groups who choose to rate legislators based on their roll call votes must 
necessarily choose their "target" votes from the set of all roll call votes taken in a given period. It is likely that there is considerable overlap in the sets of votes chosen by groups with generally similar ideological or policy orientations. For example, it would not be surprising to see two environmental groups choose similar roll call votes for their scorecards in a particular year.

McKay's project, like Groseclose and Milyo's, relies on ratings done by a third party to extrapolate ideology ratings for interest groups. These projects have made real contributions to our understanding of interest group ideology, but lose one of the most important contributions of Poole and Rosenthal's $(1985$; 1997) work; using the specific actions of groups or legislators to construct ideology scores. Such a strategy is not only more parsimonious, it also reduces any uncertainty that can creep in from other elements of the measurement strategy. In the next section, I outline a strategy for recovering interest groups' ideologies based on their patterns of lobbying the U.S. Supreme Court as amici curiae.

\section{A New Strategy for Capturing Interest Group Ideology}

I use interest group participation as amici curiae to recover an underlying ideological dimension structuring group activity. The logic is that, over time and across issues, different interest groups should find themselves on different sides of different cases, and multidimensional scaling techniques should recover and make understandable the patterns of similarity and differences that occur. In Congressional research, patterns of similarities and differences in roll-call voting are frequently used to recover the ideologies of members of Congress (Poole and Rosenthal 1997), and this same basic principle is used here.

In roll-call voting, members of Congress have three choices: to vote in support of a bill, in opposition to a bill, or to abstain from voting on the bill altogether. By the same token, in a given court case, an interest group also has three options: to file a brief on behalf of the appellant, to file a brief on behalf of the respondent, or not to file a brief. This dynamic lends itself well to the recovery of ideology. It presumes that groups will find themselves on the same side of some issues and in opposition on others. Since the Supreme Court hears cases on a wide variety of issues, coding interest group participation on cases over time should allow for understandable and quantifiable patterns of similarity and difference to emerge.

Fortunately, full-text versions of all amicus briefs filed in cases decided by the Supreme Court are available online beginning with the 1999 term to the 2007 term. ${ }^{1}$ This website contains digitized copies of each amicus brief filed in each case granted certiorari in each session. The title page of each amicus brief contains a listing of all parties participating in that brief. This 
project utilizes data from amicus briefs filed for the 1999-2002 terms of the Court. Tables 1 and 2 provide a brief description of interest group amicus curiae activity over the four terms.

The dataset is compiled as follows: rows in the data matrix are individual Supreme Court cases, while each column represents an interest group. This matrix, therefore, represents the population both of cases granted cert in the 1999-2002 terms and interest groups participating in those cases. Any group that did not file an amicus brief in a particular case is coded 0 for that case. Groups filing briefs for the petitioner are coded -1, groups filing on behalf of respondent are coded 1. Groups issuing a brief in favor of neither party (a rare event) are coded 0.

This dataset unavoidably has a large number of values of 0 , since most groups do not participate in most cases. A further limitation is that the scaling procedure used in this project is limited to scaling a maximum of 100 variables. To winnow down, I created a second dataset using all the cases and all groups filing more than four amicus briefs. This criterion was set both to increase the amount of scalable information going into the dataset

\section{Table 1. Interest Group Participation in Amicus Curiae Briefs, 1999-2003}

$\begin{array}{lc}\text { Total \# cases decided } & 341 \\ \text { \# cases w/group-sponsored } \text { amici } & 253 \\ \text { \# amicus briefs filed } & 1452 \\ \text { \# briefs sponsored by groups } & 1092 \\ \text { \# group coalition briefs } & 373 \\ \text { Mean group amici per case } & 4.32 \\ \text { \% total briefs sponsored by groups } & 75 \%\end{array}$

Table 2. Interest Group Participation in Amicus Curiae Briefs by Court Term

\begin{tabular}{lcccc}
\hline & 1999 & 2000 & 2001 & 2002 \\
\hline Total \# cases decided & 86 & 87 & 84 & 84 \\
\# cases w/group-sponsored amici & 64 & 60 & 62 & 67 \\
\# amicus briefs filed & 473 & 238 & 190 & 551 \\
\# briefs sponsored by groups & 374 & 174 & 169 & 375 \\
\# group coalition briefs & 117 & 70 & 65 & 121 \\
Mean group amici per case & 4.4 & 2.32 & 1.74 & 4.46 \\
\% total briefs sponsored by groups & $79 \%$ & $73 \%$ & $89 \%$ & $68 \%$ \\
& & & & \\
\hline
\end{tabular}


and because this cutoff left the highest number of groups (88) without reaching the limit of 100 groups. The next section provides an overview of multidimensional scaling techniques and alternative least squares scaling (ALSCAL) in particular.

\section{Multidimensional Scaling and ALSCAL}

The term "multidimensional scaling" (hereinafter MDS) refers to a set of techniques which enables a researcher to recover some type of structure that underlies a set of data (Kruskal and Wish 1990). Frequently, at least in political science, this latent structure takes the form of visualizing stimuli as points on a line (a one-dimensional structure) or in a plane (two dimensions). While some of the specific techniques subsumed into the broad category of MDS have limitations regarding the nature and type of data under consideration, techniques exist which can render virtually any data that can be translated into similarities or dissimilarities are candidates for geometrical representation (the interested reader is directed to Torgerson 1958, Takane et al. 1977, Carroll and Arabie 1980, Schiffman et al. 1981, Young and Hamer 1987, Kruksal and Wish 1990, Poole and Rosenthal 1997, Poole 1998, Borg and Groenen 1997, Van Deun and Delbeke 2000, and Cox and Cox 2001 for more technical discussions of these methods).

MDS techniques are essential tools for research in the spatial tradition of choice. If it is to be believed that the spatial proximity of buyer and seller is part of the cost of an item (Hotelling 1929) or the ideological distance between voter and candidate impacts vote choice (Downs 1957; Endersby and Cho 2003; Enelow and Hinich 1984), a reliable and valid way of recovering those proximities is necessary. While spatial proximity between buyer and seller is a straightforward exercise in map reading, recovering cognitive perceptions and political ideologies requires more sophisticated techniques. A variety of such techniques have been accepted in political science and psychological research since at least the 1970s; I provide an overview of these techniques here, and discuss one in particular, ALSCAL, which is used to scale the amicus data.

MDS techniques presume that, for a pair of objects, there exists some measure of their similarity (or conversely, dissimilarity). Similarities between different dyads can be expressed as a matrix of similarities, and all of the relationships between stimulus objects can be evaluated. Once similarities between all possible dyads of stimuli have been evaluated, the stimuli themselves can be expressed as points in a low-dimensional space (Cox and Cox 2001).

A canonical example in MDS textbooks involves a table of distances (in miles) between cities (Kruskal and Wish 1990) or flight times between 
airports (Greenacre and Underhill 1982 in Cox and Cox 2001). The distance between two cities is a ratio-level measure of their geographical proximity. MDS techniques analyze and compare patterns of difference and similarity in the distances between dyads, and ultimately present that pattern in graphical form. Kruskal and Wish $(1990,8)$ show that a table of distances between 10 U.S. cities can be unfolded to produce a mapping of those cities that is remarkably similar to where those cities are located in the real world. The choice of specific MDS technique to be employed depends upon the nature of the data under consideration.

In MDS terms, a set of data can be characterized by its number of modes and its number of ways. A dataset's number of modes refers to the number of sets of objects that underlie the data (Cox and Cox 2001, 4). For example, the inter-city distances discussed above are one-mode data; the values of the dataset are solely the distances between dyads of cities. The amicus data are two-mode data. The individual values in the dataset reflect the activity of an interest group (one mode) in a court case (the second mode). Therefore, an MDS technique suitable to two-mode data is required.

Cox and Cox state that "each index in the measurement between objects etc. is called a way." They use an example of a judge deciding how similar in flavor are two bottles of whiskey (2001, 4-5). These data have two modes, because there exist two sets of objects in the data; bottles of whiskey and judges. This data is three-way, however, because each judge is making a decision regarding the similarity of two individual bottles of whiskey. In a similar vein, my ideology data is two-way because each individual entry in the matrix represents the behavior of one group in one case. Subject to further qualification, my ideology research requires an MDS technique appropriate to two-mode, two-way data.

As in virtually all empirical research, choice of statistical method depends in part on level of measurement and "completeness" of the data. The data I analyze in this project is measured at the nominal level of measurement, contains missing data in the sense that there exists a large number of zero values, and does not directly measure proximities between dyads. Therefore, a technique must be used that can analyze nominal data with missing values, and can construct proximities between dyads as an intermediate step before presenting the graphical depiction of the data. ALSCAL is a readily-available MDS technique that meets all these criteria.

ALSCAL is a MDS procedure advanced by Yoshio Takane, Forrest Young, and Jan De Leeuw. It is positioned as a "one size fits all" procedure in that the authors claim that ALSCAL is suitable for data that may be: "(a) defined at either the nominal, ordinal, interval, or ratio level of measurement; (b) have missing observations; (c) be symmetric or asymmetric; . . . ; (f) be continuous or discrete" $(1977,7)$. Therefore, this procedure is 
empirically suitable to the ideology data, which is nominal, contains missing observations, comprises an asymmetric matrix, and has values that are discrete. Carroll and Arabie (1980) state that ALSCAL has one- and twomode capability as well as two- and three-way capability, rendering it appropriate to these data. ALSCAL is implemented as part of the SPSS system.

\section{Results and Discussion}

ALSCAL was used to generate one and two-dimensional spaces based on the amicus participation of the 88 most frequently-participating groups. The one-dimensional solution is discussed in detail here, with comments on the second dimension provided later. The results of the one-dimensional space recovered by the ALSCAL procedure are presented in a one-dimensional plot in Figure $1 .^{2}$

The anticipated interpretation of the main dimension uncovered by the procedure was that of a general ideological orientation. Generally, the spatial literature (Endersby and Galatas 1998; Poole and Rosenthal 1997; Hinich and Munger 1994; Enelow and Hinich 1984 are examples) demonstrates that much of policymaking can be explained by a unidimensional space.

Figure 1 indicates that the 10 left-most groups (as evidenced by coefficient values on the first dimension) are, in order: American Civil Liberties Union, National Association of Criminal Defense Lawyers, People for the American Way, American Association of Retired People, Public Citizen, the National Organization for Women, the National Women's Law Center,

Figure 1. Interest Group Ideology Mapping

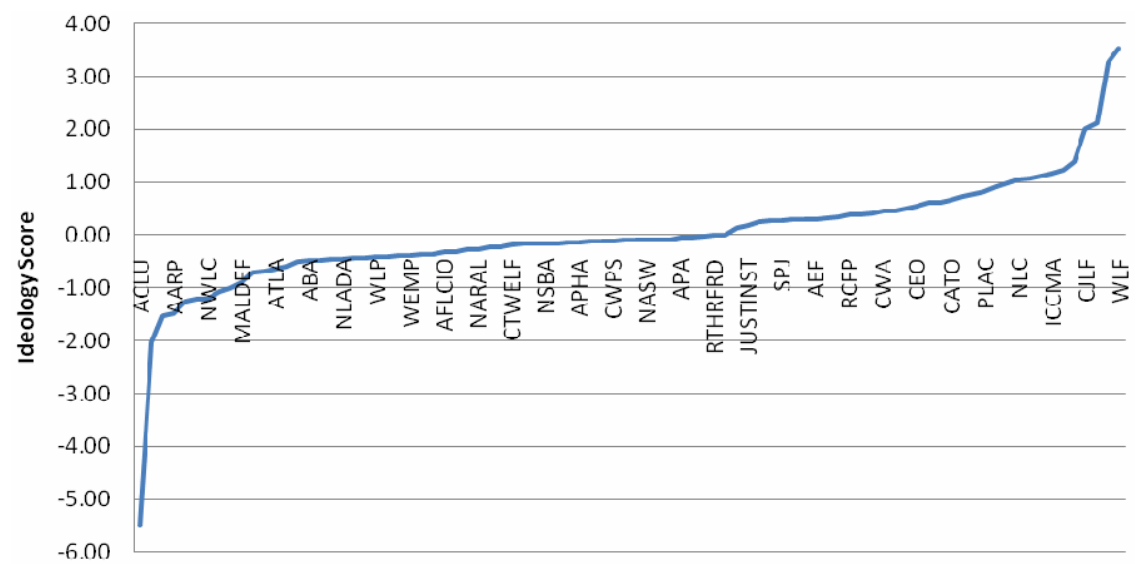


National Partnership for Women and Families, the National Congress of Jewish Women, and the Mexican-American Legal Defense and Education Fund. All of the groups can be plausibly characterized as "liberal."

Many of the 10 right-most groups recovered by the procedure also have intuitive appeal. The Pacific Legal Foundation, U.S. Chamber of Commerce, Washington Legal Foundation, American Center for Law and Justice, and Criminal Justice Legal Foundation all self-identify as conservative, probusiness, pro-family, or libertarian organizations, and appear at the opposite end of the ideological spectrum from the American Civil Liberties Union, Anti-Defamation League, and People for the American Way. The remaining five of 10 right-most groups represent the interests of state and local governments (National League of Cities, U.S. Conference of Mayors, National Association of Counties, International City-County Management Association, and the International Municipal Lawyers' Association) and do not easily fit the orthodox "conservative" label. However, closer inspection of the actual cases show that these organizations consistently argued against the interests of criminal defendants (and in favor of state/local latitude in access to counsel, administration of prisons, etc.), students, and the poor-issue stances that, among others, can reasonably be termed "conservative." Tables 3 and 4 recap the 10 most liberal and conservative groups, as uncovered by the one-dimensional ALSCAL solution.

The ordering of groups evidences a reasonable degree of face validity. Empirical measures of fit corroborate that validity. The single-dimension ALSCAL results account for 86 percent of the variation in the data $\left(\mathrm{R}^{2}=\right.$ $.865)$, while two-dimensional results capture 91 percent of the variance $\left(\mathrm{R}^{2}=\right.$ .911). The presence of a single dimension underlying behavior is common in the spatial literature, and the results uncovered here are congruent with both prior expectations and the relevant literature.

Table 3. Ten Leftmost Groups and Ideology Scores

\begin{tabular}{ll}
\hline Group & Score \\
\hline American Civil Liberties Union & -5.50 \\
National Association of Criminal Defense Lawyers & -2.04 \\
People for the American Way & -1.54 \\
American Association of Retired Persons & -1.48 \\
Public Citizen & -1.26 \\
National Organization for Women & -1.20 \\
National Women's Law Center & -1.20 \\
National Partnership for Women \& Families & -1.07 \\
National Council of Jewish Women & -1.01 \\
Mexican-American Legal Defense and Education Fund & -0.89 \\
\hline
\end{tabular}


Table 4. Ten Rightmost Groups and Ideology Scores

\begin{tabular}{lc}
\hline Group & Score \\
\hline Washington Legal Foundation & 3.54 \\
Pacific Legal Foundation & 3.27 \\
U.S. Chamber of Commerce & 2.12 \\
Criminal Justice Legal Foundation & 2.00 \\
American Center for Law \& Justice & 1.40 \\
International Municipal Lawyers Association & 1.23 \\
International City-County Management Association & 1.17 \\
National Association of Counties & 1.11 \\
U.S. Conference of Mayors & 1.06 \\
National League of Cities & 1.05 \\
\hline
\end{tabular}

Additionally, the ordering presented here appears to comport well with those established by Groseclose and Milyo (2005) and McKay (2008). While different scores computed through different methods cannot be compared directly, there exist nonparametric (distribution-free) statistical measures that can compute correlations between ordinal variables (Daniel 1990). Unfortunately, relatively few groups overlapped each project. This project had eight groups in common with Groseclose and Milyo's, and 12 in common with McKay's.

In each of these cases, I identified the groups that overlapped and ordered them in terms of their identified ideology. Next, I ranked each overlapping group from most liberal to most conservative (least liberal) as identified by each procedure, and computed Spearman's rank correlation for each pair of rankings. Table 5 provides those rankings and correlations.

Spearman rank correlation can be used for pairs of observations representing two measurements taken on the same observation. The procedure measures the extent to which the ranks of the two observations are correlated, and does not rely on assumptions about the distribution of the variables. The measure is computed as follows:

$$
\begin{aligned}
& r_{s}=1-\frac{6 \sum d_{i}^{2}}{n\left(n^{2}-1\right)}, \text { where } \\
& \sum d_{i}^{2}=\sum_{i=1}^{n}\left[R\left(X_{i}\right)\right]-\left[R\left(Y_{i}\right)\right]^{2}
\end{aligned}
$$

The results recovered from the amicus briefs correlate well with those based on ADA and NOMINATE scores, and have the benefit of being recovered directly from the lobbying activities of the groups themselves. 
Table 5. Correlations of Ranked Ideology Scores with Previous Work

\begin{tabular}{|c|c|c|}
\hline Group & Amicus Data & $\begin{array}{c}\text { Groseclose } \\
\& \text { Milyo }\end{array}$ \\
\hline American Association of Retired Persons & 3 & 3 \\
\hline American Civil Liberties Union & 1 & 5 \\
\hline Cato Institute & 8 & 7 \\
\hline Family Research Center & 7 & 8 \\
\hline National Association for the Advancement of Colored People & 5 & 4 \\
\hline National Abortion Rights Action League & 6 & 6 \\
\hline National Organization for Women & 4 & 1 \\
\hline People for the American Way & 2 & 2 \\
\hline \multicolumn{3}{|l|}{$r_{\mathrm{s}}=0.67, r_{\text {crit }}=0.72$} \\
\hline Group & Amicus Data & McKay \\
\hline American Association of University Women & 5 & 2 \\
\hline American Public Health Association & 8 & 6 \\
\hline Campaign for Corporate Reform & 6 & 1 \\
\hline Eagle Forum & 11 & 12 \\
\hline Family Research Council & 10 & 11 \\
\hline Hadassah & 2 & 9 \\
\hline Human Rights Campaign & 9 & 8 \\
\hline National Association for the Advancement of Colored People & 4 & 3 \\
\hline National Abortion Rights Action League & 7 & 4 \\
\hline National Education Association & 3 & 7 \\
\hline Public Citizen & 1 & 2 \\
\hline U.S. Chamber of Commerce & 12 & 10 \\
\hline$r_{\mathrm{s}}=0.61, \mathrm{p}=0.036$ & & \\
\hline
\end{tabular}

Ranking the eight groups common to this project and Groseclose and Milyo's (2005) show six of the eight ranks are within one place of each other, with two notable differences. My results have the ACLU as the most liberal group, both overall and in the subset of groups that overlap. Groseclose and Milyo's rankings have the ACLU in fifth place. Their results have NOW as the most-liberal group in the subset, but NOW is fourth in my rankings. The ranks correlate to 0.67 , less than the critical value of 0.72 required for a two-tailed significance test at the 0.05 level.

McKay's (2008) results and mine are correlated at 0.61, significant at the 0.05 level $(t=2.42)$. Again, most of the ranks are within two places of each other, with two exceptions. McKay's results have the Campaign for Corporate Reform as the leftmost in the subset, but they are sixth in my 
rankings. I have the National Education Association as the third most liberal group in the subset, but they are seventh in McKay's. These differences could be due to the lack of power of the correlation statistic, the methods used to generate the ideology, or simply due to chance in terms of which groups overlapped both studies. Ultimately, the substantive significance of the scores should be their use in other contexts, such as predicting patterns of similarity and difference in other contexts.

A few words on the second dimension structuring the data are in order. ALSCAL recovered a second dimension which accounts for about 5 percent of the variation in preferences. When this project was conceived, it was hypothesized that any second dimension might be interpreted as a group's inside/outside orientation, pursuant to Kollman (1998). It is fair to say that preliminary indications do not bear out the interpretation of inside/outside orientation. Such an interpretation would be borne out by an ordering of dimension two scores with policy/litigation types of organizations (examples would be the Washington and Pacific Legal Foundations) on the opposite sides of more grassroots-oriented groups like NOW or the NRA. Such an ordering does not emerge.

The second dimension is instead anchored by the National Association of Criminal Defense Lawyers, U.S. Chamber of Commerce, American Civil Liberties Union, Cato Institute, Product Liability Advisory Council, and Pacific Legal Foundation on one side and the Criminal Justice Legal Foundation, American Association of Retired Persons, National League of Cities, U.S. Conference of Mayors, and People for the American Way, an ordering that defies easy conceptualization. At this time, no interpretation of the meaning of the second dimension is forthcoming, given the low explanatory power and lack of ready theoretical definition.

\section{Conclusions and Comments}

The empirical results presented above represent an important step in extending the spatial theory of choice to the study of organized interests by demonstrating that interest group ideology can be captured in a valid and reliable manner similar to methods commonly used to measure legislator ideology. This begins with an attempt to provide a sketch of the scope of interest group lobbying of the Supreme Court through participation on amicus curiae briefs. Participation in these briefs is a relatively low-cost way for groups to be active in the policy process, especially in contrast to a full-scale Congressional lobbying campaign, and the brief examination of that participation set forth in Tables 1 and 2 confirms that a large, diverse range of groups are in fact active in lobbying the Court with amicus briefs. 
The utility of the recovered scores will ultimately be testable through their performance in predicting actual patterns of lobbying collaboration and opposition, the next phase of this project. However, the amicus data presented here offer some evidence of ideological structuring of interest group partnership in lobbying the Supreme Court.

In the entire dataset, there were 373 briefs coauthored by two or more interest groups. As an initial investigation of how well the broader relationships indicated by the one-dimensional mapping might hold up to empirical analysis, I divided the ordered list of 88 groups into thirds; the 29 left and right-most groups, and the 30 groups remaining in the middle of the mapping. Notwithstanding the individual coefficients for groups, if the mapping is valid, we should see more cooperation between proximate groups than with groups further away.

This is overwhelmingly the case. In examining all coauthored briefs in the cases, no brief features a partnership of a group on the leftmost third with a group on the rightmost. Left-center and right-center partnerships are more common. In the briefs examined, 86 such briefs exist, so such briefs account for approximately 25 percent of all coauthored briefs. In the final analysis, it seems likely that a great deal of interest group cooperation occurs between ideologically proximate groups.

Table 6 shows a table of all the amicus coalition partners for a selection of groups frequently active before the Supreme Court: the American Civil Liberties Union, Cato Institute, U.S. Chamber of Commerce, the National Organization for Women, the American Association of Retired Persons, and the American Center for Law and Justice.

This table demonstrates a remarkable amount of homogeneity in partner selection, at least for these frequent participators before the Court. Fifteen of the ACLU's 21 coalition briefs were authored with partners solely from the leftmost third of the mapping, and its most frequent partners are all from the leftmost third as well. Nor is the ACLU's behavior unique on the left side. A majority of NOW's coalitions involved only partners on the left, and exactly half of AARP's coalitions are homogeneous as well.

On the right, the ACLJ (a litigation organization founded by Pat Robertson) participated in six coalitions, five with Focus on the Family, a conservative Christian organization founded by Rev. James Dobson. The Cato Institute's five coalition briefs with other members of the 88 groups include only matchups with groups to the right of center, as do all eight filed by the U.S. Chamber of Commerce. These empirical results prompt optimism that the ideology coefficients will perform well in statistical models of interest group activity.

Since much of the spatial literature rests on the assumption that proximity, in the sense of "closeness" in terms of ideology or desired policy, is a 
Table 6. Selected Interest Groups and Amicus Coalition Partners

\begin{tabular}{|c|c|c|c|}
\hline Group & Briefs Filed & Coalitions & Frequent Partners \\
\hline NOW & 21 & 16 & $\begin{array}{l}\text { Anti-Defamation League }-8 \\
\text { Northern Women's Law Center }-7 \\
\text { Women's Law Partners }-7 \\
\text { Women Employed }-7 \\
\text { Northwest Women's Law Center }-6 \\
\text { ACLU - } 7\end{array}$ \\
\hline ACLU & 50 & 31 & $\begin{array}{l}\text { NOW }-7 \\
\text { Nat'l Assn Criminal Defense Lawyers }-6 \\
\text { Northern Women's Law Center }-5 \\
\text { People for the American Way }-4\end{array}$ \\
\hline AARP & 22 & 14 & $\begin{array}{l}\text { NOW - } 4 \\
\text { Mexican-American Legal Defense }-3 \\
\text { National Employment Lawyers Assn }-5\end{array}$ \\
\hline CATO & 14 & 9 & $\begin{array}{l}\text { Center for Individual Freedom - } 3 \\
\text { Eagle Forum }-2 \\
\text { Nat'l Assn Criminal Defense Lawyers - } 1\end{array}$ \\
\hline ACLJ & 13 & 6 & Focus on the Family -5 \\
\hline USCC & 31 & 17 & $\begin{array}{l}\text { Equal Employment Access Center - } 4 \\
\text { National Assn of Manufacturers }-3 \\
\text { Product Liability Advisory Council - } 1\end{array}$ \\
\hline
\end{tabular}

key factor influencing choice, a spatial model of coalition partner selection is predicated on the ability to generate an accurate map of interest group ideological positions, either in terms of a general orientation toward the policy world or on an issue-by-issue basis. To this end, the unfolding presented herein represents a vital step in this endeavor. These results indicate that MDS procedures applied to Supreme Court lobbying data generate a mapping of interest group ideology that has intuitive appeal and empirical validity. The next phase of this project will use the recovered ideology scores as predictors of actual interest group lobbying partnerships. 


\section{APPENDIX}

\section{Interest Group Names, Codes, and 1-Dimensional Ideology Scores}

\begin{tabular}{|c|c|c|}
\hline American Civil Liberties Union & ACLU & -5.50 \\
\hline National Association of Criminal Defense Lawyers & NACDL & -2.04 \\
\hline People for the American Way & PFAW & -1.54 \\
\hline American Association of Retired Persons & AARP & -1.48 \\
\hline Public Citizen & PUBCIT & -1.26 \\
\hline National Organization for Women & NOW & -1.20 \\
\hline National Women's Law Center & NWLC & -1.20 \\
\hline National Partnership for Women and Families & NPWF & -1.07 \\
\hline National Council of Jewish Women & NCJW & -1.01 \\
\hline Mexican-American Legal Defense and Education Fund & MALDEF & -0.89 \\
\hline National Employment Lawyers Association & NELA & -0.71 \\
\hline Anti-Defamation League & $\mathrm{ADL}$ & -0.69 \\
\hline American Trial Lawyers Association & ATLA & -0.64 \\
\hline National Organization of Women Legislators & NOWL & -0.60 \\
\hline National Asian and Pacific-American Legal Center & NAPALC & -0.51 \\
\hline American Bar Association & ABA & -0.49 \\
\hline Trial Lawyers for Public Justice & TLPJ & -0.49 \\
\hline Hadassah & HADASSAH & -0.46 \\
\hline National Legal Aid \& Defender Association & NLADA & -0.46 \\
\hline Feminist Majority Foundation & FMF & -0.44 \\
\hline Northwest Women's Law Clinic & NWWLC & -0.44 \\
\hline Women's Law Partners & WLP & -0.42 \\
\hline National Education Association & NEA & -0.41 \\
\hline Asian-American Legal Defense \& Education Fund & AALDEF & -0.38 \\
\hline Women Employed & WEMP & -0.38 \\
\hline National Association for the Advancement of Colored People & NAACP & -0.37 \\
\hline Puerto Rican Legal Defense \& Education Fund & PRLDEF & -0.36 \\
\hline AFL-CIO & AFLCIO & -0.33 \\
\hline American Association of University Women & AAUW & -0.31 \\
\hline Center for Constitutional Rights & CCR & -0.27 \\
\hline National Abortion Rights Action League & NARAL & -0.27 \\
\hline Lawyers Committee for Civil Rights Under Law & LCCRUL & -0.24 \\
\hline American College of Obstetricians \& Gynecologists & ACOBGYN & -0.22 \\
\hline Connecticut Women's Education and Legal Fund & CTWELF & -0.18 \\
\hline Association of Federal Defenders & AFD & -0.16 \\
\hline Brennan Center for Justice & BCJNYULS & -0.15 \\
\hline National Small Business Association & NSBA & -0.15 \\
\hline Union of American Hebrew Congregations & UAHC & -0.15 \\
\hline Jewish Committee on Public Affairs & JCPA & -0.14 \\
\hline American Public Health Association & APHA & -0.13 \\
\hline Equal Rights Action & ERA & -0.12 \\
\hline New York City Bar Association & NYCBAR & -0.12 \\
\hline Center for War \& Peace Studies & CWPS & -0.11 \\
\hline Baptist Joint Committee on Public Affairs & BJCPA & -0.10 \\
\hline
\end{tabular}




\section{APPENDIX (continued)}

\begin{tabular}{|c|c|c|}
\hline Human Rights Action & HRA & -0.10 \\
\hline National Association of Social Workers & NASW & -0.10 \\
\hline Human Rights Campaign & $\mathrm{HRC}$ & -0.09 \\
\hline National Gay Lesbian and Transgendered Foundation & NGLTF & -0.09 \\
\hline American Physicians Association & APA & -0.05 \\
\hline United Church of Christ Justice and Witness Ministries & UCCJWM & -0.05 \\
\hline Disability Rights Education and Defense Fund & DREDF & -0.03 \\
\hline Rutherford Institute & RTHRFRD & -0.01 \\
\hline National Association of Consumer Advocates & NACA & 0.00 \\
\hline American Medical Association & AMA & 0.14 \\
\hline Justice Institute & JUSTINST & 0.18 \\
\hline Lincoln Institute for Research and Education & LIRE & 0.26 \\
\hline Liberty Counsel & LIBCNSL & 0.28 \\
\hline Society of Professional Journalists & SPJ & 0.28 \\
\hline Health Insurance Association of America & HIAA & 0.29 \\
\hline National Sheriffs Association & NSA & 0.29 \\
\hline Allied Educational Foundation & $\mathrm{AEF}$ & 0.30 \\
\hline Christian Legal Society & CLS & 0.31 \\
\hline Becket Fund for Religious Liberty & BFRL & 0.35 \\
\hline Reporters Committee for Freedom of the Press & RCFP & 0.38 \\
\hline Family Research Center & FRC & 0.39 \\
\hline Eagle Forum & EAGLE & 0.40 \\
\hline Concerned Women for America & CWA & 0.45 \\
\hline Focus on the Family & FOCFAM & 0.46 \\
\hline National Council of State Legislators & NCSL & 0.50 \\
\hline Center for Equal Opportunity & CEO & 0.54 \\
\hline Center for Individual Freedom & $\mathrm{CIF}$ & 0.62 \\
\hline National Governors Association & NGA & 0.62 \\
\hline Cato Institute & CATO & 0.67 \\
\hline Claremont Institute for Constitutional Jurisprudence & CICJ & 0.73 \\
\hline National Association of Manufacturers & NAM & 0.78 \\
\hline Product Liability Advisory Council & PLAC & 0.81 \\
\hline Equal Employment Access Center & EEAC & 0.92 \\
\hline Council of State Governments & CSG & 0.97 \\
\hline National League of Cities & NLC & 1.05 \\
\hline U.S. Conference of Mayors & MAYORS & 1.06 \\
\hline National Association of Counties & NACTY & 1.11 \\
\hline International City-County Management Association & ICCMA & 1.17 \\
\hline International Municipal Lawyers Association & IMLA & 1.23 \\
\hline American Center for Law and Justice & ACLJ & 1.40 \\
\hline Criminal Justice Legal Foundation & CJLF & 2.00 \\
\hline U.S. Chamber of Commerce & USCC & 2.12 \\
\hline Pacific Legal Foundation & PLF & 3.27 \\
\hline Washington Legal Foundation & WLF & 3.54 \\
\hline
\end{tabular}




\section{NOTES}

${ }^{1}$ The briefs are available at http://supreme.lp.findlaw.com/supreme court/briefs/ index.html. The cover page for each brief lists all authors. The authors were input into the dataset after reading each brief's cover page.

${ }^{2}$ Figure 1 identifies groups by the variable name assigned to each group during coding. A complete list of groups, codes, and ideology score is provided in the Appendix.

\section{REFERENCES}

Baumgartner, Frank R., and Beth L. Leech. 1998. Basic Interests: The Importance of Groups in Politics and in Political Science. Princeton: Princeton University Press.

Berry, Jeffrey M. 1997. The Interest Group Society, 3rd ed. New York: Longman.

Borg, Ingwer, and Patrick Groenen. 1997. Modern Multidimensional Scaling: Theory and Applications. New York: Springer.

Caldeira, Gregory A., and John R. Wright. 1988. Organized Interests and Agenda Setting in the U.S. Supreme Court. American Political Science Review 82:1109-1127.

Caldeira, Gregory A., and John R. Wright. 1990. Amici Curiae Before the Supreme Court: Who Participates, When, and How Much? The Journal of Politics 52:782-806.

Carpenter, Daniel P., Kevin M. Esterling, and David M.J. Lazer. 2004. Friends, Brokers, and Transitivity: Who Informs Whom in Washington Politics? Journal of Politics 66:224-246.

Carroll, J. Douglas, and Phipps Arabie. 1980. Multidimensional Scaling. Annual Review of Psychology 31:607-649.

Cox, Trevor F., and Michael A.A. Cox. 2001. Multidimensional Scaling, 2nd ed. Boca Raton, FL: Chapman \& Hall.

Daniel, Wayne W. 1990. Applied Nonparametric Statistics. Boston: PWS-Kent.

Downs, Anthony. 1957. An Economic Theory of Democracy. New York: Harper \& Row.

Endersby, James W., and Sungdai Cho. 2003. Issues, Spatial Models of Voting, and British General Elections: A Comparison of Proximity and Directional Models. Public Choice 114:275-293.

Endersby, James W., and Steven E. Galatas. 1998. British Parties and Spatial Competition: Dimensions of Party Evaluation in the 1992 Election. Public Choice 97:363382.

Enelow, James M., and Melvin J. Hinich. 1984. The Spatial Theory of Voting: An Introduction. Cambridge: Cambridge University Press.

Epstein, Lee, and C.K. Rowland. 1991. Debunking the Myth of Interest Group Invincibility in the Courts. American Political Science Review 33:825-841.

Groseclose, Tim, and Jeff Milyo. 2005. A Measure of Media Bias. Quarterly Journal of Economics 120:1191-1237.

Hansford, Thomas G. 2004. Information Provision, Organizational Constraints, and the Decision to Submit an Amicus Curiae Brief in a U.S. Supreme Court Case. Political Research Quarterly 57:219-230.

Hinich, Melvin J., and Michael C. Munger. 1994. Ideology and the Theory of Political Choice. Ann Arbor: University of Michigan Press.

Hojnacki, Marie, and David C. Kimball. 1998. Organized Interests and the Decision of Whom to Lobby in Congress. American Political Science Review 92:775-790. 
Holyoke, Thomas T. 2003. Choosing Battlegrounds: Interest Group Lobbying Across Multiple Venues. Political Research Quarterly 56:325-336.

Holyoke, Thomas T. 2004. Lobbying Strategies, Venue Selection, and Organized Interest Involvement at the U.S. Supreme Court. American Politics Research 32:170-197.

Hotelling, Harold. 1929. Stability in Competition. The Economic Journal 39:41-57.

Kollman, Ken. 1997. Inviting Friends to Lobby: Interest Groups, Ideological Bias, and Congressional Committees. American Journal of Political Science 41:519-544.

Kollman, Ken. 1998. Outside Lobbying: Public Opinion \& Interest Group Strategies. Princeton: Princeton University Press.

Koshner, Andrew Jay. 1998. Solving the Puzzle of Interest Group Litigation. Westport, CT: Greenwood Press.

Kruskal, Joseph B., and Myron Wish. 1990. Multidimensional Scaling. London: SAGE Publications.

Lowery, David, and Holly Brasher. 2004. Organized Interests and American Government. New York: McGraw-Hill.

McGuire, Kevin T. 1994. Amici Curiae and Strategies for Gaining Access to the Supreme Court. Political Research Quarterly 47:793-820.

McKay, Amy. 2008. A Simple Way of Estimating Interest Group Ideology. Public Choice 136:69-86.

Nownes, Anthony J. 2001. Pressure and Power: Organized Interests in American Politics. Boston, MA: Houghton Mifflin.

Poole, Keith T. 1998. Recovering a Basic Space from a Set of Issue Scales. American Journal of Political Science 42:954-993.

Poole, Keith T., and Tom Romer. 1985. Patterns of PAC Contributions to the 1980 Campaign for the U.S. House of Representatives. Public Choice 47:63-111.

Poole, Keith T., and Howard Rosenthal. 1997. Congress: A Political-Economic History of Roll-Call Voting. New York: Oxford University Press.

Schlozman, Kay Lehman, and John T. Tierney. 1986. Organized Interests and American Democracy. New York: Harper and Row.

Schiffman, Susan S., M. Lance Reynolds, and Forrest W. Young. 1981. Introduction to Multidimensional Scaling: Theory, Methods, and Applications. New York: Academic Press.

Spaeth, Harold, Lee Epstein, Ted Ruger, Keith Whittington, Jeffrey Segal, and Andrew D. Martin. 2010. The Supreme Court Database: 2010 Release 02. 26 August 2010. http://scdb.wustl.edu/data.php. 12 November 2010.

Spriggs, James F. II, and Paul J. Wahlbeck. 1997. Amicus Curiae and the Role of Information at the Supreme Court. Political Research Quarterly 50:365-386.

Takane, Yoshio, Forrest W. Young, and Jan De Leeuw. 1977. Nonmetric Individual Differences Multidimensional Scaling: An Alternating Least Squares Method with Optimal Scaling Features. Psychometrika 42:7-66.

Torgerson, Warren S. 1958. Theory and Methods of Scaling. New York: John Wiley \& Sons.

Van Deun, Katrijn, and Luc Delbeke. 2000. Multidimensional Scaling. Located at http://www.mathpsyc.uni-bonn.de/doc/delbeke/delbeke.htm.

Young, Forrest W., and Robert M. Hamer, eds. 1987. Multidimensional Scaling: History Theory, and Applications. Hillsdale, NJ: Lawrence Erlbaum Associates. 